\title{
Doktrin Tritunggal Kebenaran Alkitabiah
}

\author{
Eko Wahyu Suryaningsih \\ Sekolah Tinggi Teologi Baptis Indonesia Semarang \\ ekowahyusuryaningsih@gmail.com
}

\begin{abstract}
ABSTRAK
Doktrin Allah Tritunggal merupakan doktrin dalam ajaran Kristen yang seringkali menjadi bahan polemik baik di dalam lingkungan Kristen maupun dari luar lingkungan Kristen, karena seringkali dianggap sebagai sesuatu yang tidak masuk akal. Berhubung dengan permasalahan di atas, maka penulis akan berusaha untuk memberikan pengajaran doktrin Allah Tritunggal berdasarkan Firman Allah sehingga dapat memberikan sumbangsih bagi pengajaran umat Kristen secara kusus dan para pembaca secara umum. Allah yang dapat kita kenal adalah sebatas apa yang dinyatakan dalam Alkitab. Allah yang menyatakan dalam Alkitab adalah Allah Tritunggal. Inilah yang harus dipahami oleh umat Kristiani. Ada hal-hal yang sepertinya kontradiksi tetapi sebenarnya bukan kontradiksi melainkan suatu misteri, yaitu misteri Allah yang tidak mungkin dipahami secara sempurna dengan kemampuan manusia yang terbatas. Bagian kita adalah memahami apa yang dinyatakan-Nya dalam Alkitab.
\end{abstract}

Kata kunci: Tritunggal, Allah, Anak, Roh Kudus, Bapa.

\section{PENDAHULUAN}

Doktrin Allah Tritunggal adalah pengajaran penting dan sentral dalam iman Kristen yang berhubungan dengan pengakuan akan Tuhan. Selain sebagai doktrin yang penting, doktrin Allah Tritunggal juga merupakan doktrin dalam ajaran Kristen yang seringkali menjadi bahan polemik baik di dalam lingkungan Kristen maupun dari luar lingkungan Kristen, karena seringkali dianggap sebagai sesuatu yang tidak masuk akal. Seringkali tuduhan politeisme ditujukan kepada iman Kristen karena pengajaran Allah Tritunggal ini. Ada kelompok yang beranggapan bahwa Allah orang Kristen bukan Allah yang Esa. Permasalahan ini dapat dimengerti karena doktrin Allah Tritunggal bukan merupakan doktrin yang mudah dimengerti dan ajaran ini bukan ajaran manusiawi tetapi sebuah doktrin yang berdasarkan Alkitab.

Dalam konteks anggota gereja sendiri, ada beberapa anggota gereja yang tidak mau berurusan dengan doktrin Allah Tritunggal karena ketidak mengertian mereka terhadap ajaran ini. Ada sebagian orang Kristen yang beranggapan bahwa doktrin Allah Tritunggal adalah urusan para teolog bukan urusan jemaat awam. Meskipun secara praktis mereka beribadah dan menyembah Allah Tritunggal, tetapi apabila memasuki wilayah doktrinal maka sebagian jemaat yang tidak mengerti.

Oleh karena alasan ini maka gereja perlu untuk memberikan pengajaran yang benar tentang Allah Tritunggal sesuai dengan pengajaran Kitab Suci. Dengan pengajaran yang benar akan dapat meminimalkan kesalah mengertian tentang doktrin Allah Tritunggal baik dalam konteks internal maupun eksternal. Berhubung dengan permasalahan di atas, maka penulis akan berusaha untuk memberikan pengejaran doktrin Allah Tritunggal berdasarkan Firman Allah sehingga dapat memberikan sumbangsih bagi pengajaran umat Kristen secara kusus dan para pembaca secara umum. 


\section{METODE PENELITIAN}

Penelitian ini menggunakan metode kualitatif deskriptif. Penelitian ini tergolong dalam penelitian kepustakaan. Penelitian kepustakaan pada penelitian ini dilakukan dengan cara mempelajari dokumen atau hasil penelitian terdahulu dan berbagai buku yang berkaitan dengan teologi dan doktrin Tritunggal.

\section{PEMBAHASAN}

\section{Sejarah Perumusan Doktrin Allah Tritunggal}

Dalam sejarah gereja, ajaran Allah Tritunggal merupakan ajaran yang mempunyai sejarah panjang dan menjadi bahan kontroversi sebelum akhirnya mencapai formulasi yang baku. Pertamatama ajaran ini muncul di tengah monotheisme Yahudi yang kuat "Dengarlah, hai orang Israel: TUHAN itu Allah kita, TUHAN itu esa (satu)!" (Ul. 6:4), sehingga ajaran tentang Tuhan yang Esa tetapi dikenal dalam tiga pribadi bukan ajaran yang mudah untuk diterima. Kedua, ajaran Allah Tritunggal juga berada dalam konteksYunani-Romawi yang menekankan pada bentuk-bentuk yang logis dan filsafat. Oleh sebab itu menurut Van Den End, “. . ajaran Alkitab tentang Allah dan Kristus tak boleh tidak harus 'diterjemahkan' ke dalam bentuk-bentuk lingkungan YunaniRomawi."

Hal ini perlu karena istilah Allah Tritunggal atau Trinitas sendiri bukan istilah yang dinyatakan secara eksplisit dalam Alkitab, "The doctrine of the Trinity is given to us in the Scriptural, not in formulated definition, but in fragmentary allusions." 2 Di sinilah perlunya gereja, yang pada waktu itu diwakili oleh Bapabapa gereja, berusaha supaya dapat menyatakan imannya kepada dunia YunaniRomawi. Bapa-bapa gereja berusaha untuk

${ }^{1}$ Harta dalam Bejana (Jakarta: Gunung Mulia, 1987) 71.

${ }^{2}$ Benyamin B. Warfield, Biblical and Theological Study (Philadelphia: Presbyterian and Reformed, 1968) 22. dapat menerjemahkan pernyataan Alkitab tentang Allah dalam bahasa yang jelas sehingga dapat dimengerti dan menghindarkan kesalahmengertian tentang ajaran Allah Tritunggal.

Secara teknis istilah Trinitas atau Tritunggal pertama kali dipakai oleh Bapa Gereja Afrika Utara Tertulian (160-220). Salah satu rumusan tentang doktrin Allah Tritunggal dari Bapa-bapa gereja adalah hasil konsili Konstantinopel. ${ }^{3}$ Selain itu karya literatur besar sehubungan dengan Trinitas adalah De Trinitate dari Augustinus. Dalam buku ini Augustinus memberikan penjelasan mengenai doktrin Allah Tritunggal yang dipercayai oleh iman Kristen untuk tujuan apologetik terhadap aliran-aliran sesat. Menurut John Burnaby, setengah bagian dari buku De Trinitate berkaitan dengan problem-problem yang muncul dalam doktrindoktrin Katolik yaitu: (a) bahwa Tuhan adalah satu (esa) dan bahwa kesatuan Trinitas aktif dalam semua tindakan ilahi-Nya (divine operation), (b) bahwa tiga "Pribadi" berbeda satu dengan yang lain sejak keberadaanya yang kekal. $^{4} \quad$ Meskipun mengalami kontroversi panjang, doktrin Allah Tritunggal bukanlah merupakan doktrin yang diciptakan oleh gereja atau Bapa-bapa gereja semata. Seperti halnya pendapat Alan Roxburgh tentang doktrin Allah Tritunggal, di mana ia mengatakan:

The doctrine of the Trinity is not an abstract dogma created by the church out of some social need to convert pagans or to argue with Greek philosophers. The confession of God as Trinity was a response to the love of the Father, the historical reality of Jesus Christ, and the experience of the Holy Spirit. ${ }^{5}$

Secara umum pemahaman yang benar mengenai Allah Tritunggal yang diajarkan oleh Bapa Gereja hingga kini adalah Sebagai berikut:

Bahwa Allah adalah Allah yang Esa, Bahwa Allah Bapa, Allah Anak dan Allah Roh Kudus adalah Allah yang Esa Serta Bahwa Allah Bapa, Allah Anak dan Allah Roh Kudus adalah tiga pribadi yang masing-masing berbeda.

${ }^{3}$ Lihat G. C. Van Niftrik dan B. J. Boland, Dogmatika Masa Kini (Jakarta: Gunung Mulia, 1984) 568.

${ }^{4}$ Augustine Later Works (Philadelphia: Westminster, t.t) 19.

5"Rethinking Trinitarian Missiology" dalam Global Missiology for $21^{\text {St }}$ Century (Grand Rapids: Baker Academic, 2000) 181. 


\section{Pernyataan Teologis Doktrin Allah Tritungal \\ Latar Belakang}

Mulai abad kedua, ketika penghambatan yang berasal dari luar mulai berkurang, gereja dapat menjalankan tugas dan panggilannya dengan lebih baik. Tetapi justru pada saat-saat inilah permasalahan dari dalam gereja sendiri mulai timbul. Pokok permasalahannya adalah mengenai perumusan doktrin yang berhubungan dengan Allah, yang akhirnya menjadi bahan perdebatan. Salah satunya adalah perdebatan tentang doktrin Trinitas/Tritunggal

Menurut Van den End, yang menjadi persoalan sehubungan dengan Trinitas ialah bahwa, ". . . ajaran Alkitab tentang Allah dan Kristus tak boleh tidak harus "diterjemahkan" ke dalam bentuk-bentuk lingkungan Yunani-Romawi."6 Pemikiran Yunani-Romawi yang lebih suka pada bentuk-bentuk yang logis, bertemu dengan pernyataan Alkitab mengenai Tuhan yang sepertinya bertentangan dengan logika, dimana Allah Yang Esa, tetapi dikenal atau menyatakan diri dalam tiga oknum atau pribadi. O1eh sebab itu Bapak-bapak geraja berusaha untuk "menerjemahkan" pernyataan Alkitab tentang Allah kepada dunia Yunani-Romawi. Di sini perlunya gereja, yang diwakili oleh Bapak-bapak gereja, untuk menyatakan imannya dalam satu bahasa yang jelas dan dapat diartikulasikan secara konseptual, yang tentunya juga tidak dapat begitu saja terpisah dengan istilah dan konsep-konsep filosofis yang umum digunakan pada jaman itu.

Yang menjadi permasalahan dalam memformulasikan pernyataan Alkitab tentang doktrin Trinitas adalah pemahaman para tokoh gereja berbeda-beda, yang tentunya dipengaruhi oleh latar belakang filosofis dan teologia mereka masingmasing, sehingga mengakibatkan timbulnya perbedaan pendapat. yang tajam, bahkan tidak jarang terjadi saling mengutuk dan

\footnotetext{
${ }^{6}$ Van Den End, Harta dalam Bejana (Jakarta:

Gunung Mulia, 1987) 71.
}

saling mengucilkan antara tokoh-tokoh gereja yang berbeda pendapat ini.

\section{Perkembangan Pemikiran tantang Allah Tritunggal}

Dalam sejarah perkembangan pemikiran tentang doktrin Allah Tritungal di antara Bapakbapak gereja, pada umumnya dapat ditemukan adanya dua golongan pemikiran yang ekstrim.

Golongan yang menekankan Keesaan Allah sehingga melemahkan Ketritunggalan Allah. Dalam pandangan ini Allah Bapa, Anak dan Roh Kudus dipandang hanya sebagai sifat atau cara keberadaan Allah yang berbeda, dan merupakan satu pribadi saja, seperti misalnya:

a. Doketisme yang mengajarkan bahwa Kristus bukan manusia sejati

b. Ebionisme yang mengajarkan bahwa Kristus bukan Allah sejati.

c. Monarchianism yang secara umum dapat dipisahkan menjadi dua kelompok yaitu Dynamic Monaschianism yang menyatakan bahwa Yesus hanyalah manusia biasa yang pada akhirnya di adopsi oleh Allah Bapa ketika dibaptis atau mungkin ketika kebangkitan. Aliran ini juga disebut sebagai Adoptianism yang dipelopori oleh Paul of Samosota. Kedua, Modalictic Monarchianism, yang menyatakan bahwa Allah berubah dalam keberadaannya di setiap masa. Praxeas mengajarkan bahwa Tuhan Allah adalah Roh. Maka sebagai Roh maka Ia disebut sebagai Bapa. Allah Bapa ini kemudian mengenakan daging atau menjadi manusia yang disebut Anak atau Yesus (dalam bentuk daging) dan Kristus $($ Roh-Nya $=$ Bapa $)$. Sebab itu pada waktu Yesus disalibkan, Bapa juga turut menderita seperti Kristus (aliran ini juga disbut Patripassianime artinya Bapa turut menderita). Pemikiran serupa seperti yang diajarkan oleh Sebellius (Sabelianisme) menyatakan bahwa Allah Bapa, Anak dan Roh Kudus adalah penampakan satu Allah dalam tiga bentuk PL sebagai Allah Bapa, PB sebagai Juruselamat (Anak) dan pada masa Pentakosta sebagai Roh Kudus. 
Golongan yang menekankan Ketritunggalan Allah sehingga melemahkan Keesaan Allah. Dalam kelompok ini Allah Bapa Anak dan Roh Kudus dipandang berbeda satu dengan lainnya tanpa ada kesatuan (triteisme). Salah satu contoh dari golongan ini adalah Arianisme yang mengajarkan bahwa Kristus adalah ciptaan Allah. Arius 250-336 M) mengajarkan bahwa Yesus Kristus memiliki permulaan, jadi Ia bukanlah pribadi yang kekal. Bagi Arius Kristus adalah pribadi ilahi tingkat dua (deoteros teos) yang diciptakan oleh Bapa. Dengan demikian ia menolak subtansi yang sama ( $\mathrm{h}<$ mousios) Aliran ini kemudian dinyatakan sebagai bidat pada Konsili Nicea pada tahun $325 \mathrm{M}$. Pada masa kini pandangan yang menganggap Kristus sebagai ciptaan Bapa ini dikembangkan dan dianut oleh kelompok Saksi Yehova.

Pada akhirnya pergumulan teologis tentang Allah Tritunggal dari Bapa-bapa gereja disahkannya sebagai formulasi Allah Tritunggal yang disampaikan oleh Tertulianus.Tertulianus memulai ajarannya tentang Allah dengan "pribadi Allah, Bapa dan yang bersama-sama dengan Dia, Firman dan Hikmat, yang melahirkan keduanya dengan tujuan penciptaan dunia." Dalam karyanya Adversus Praxean tahun 213 M Tertulianus menyatakan bahwa Keberadaan Allah adalah tiga pribadi satu subtansi. (Latin: tres personae, una subtantia). ${ }^{8}$

\section{Perbedaan Pribadi dalam Allah Tritunggal}

Secara substansi dan kuasa dalam Allah Tritunggal tidak dapat dipisahkan, namun demikian juga ada keistimewaan atau perbedaan dalam tiap pribadi. Dalam Alkitab dinyatakan bahwa Allah Bapa, Anak dan Roh Kudus masing-masing bekerja dalam otoritas dan cara tersendiri. Seperti misalnya dalam Yohanes 16:4b-11. Dengan demikian dapat dikatakan sebagai berikut:

\section{Secara Ontologis:}

${ }^{7}$ Bernhard Lohse, Pengantar Sejarah Dogmna Kristen (Jakarta: Gunung Mulia, 1994) 56.
Ini mengacu kepada sifat kekekalan Allah Tritunggal, yakni masing-masing pribadi memiliki substansi yang sama. Dengan demikian dapat dikatakan bahwa secara ontologi dalam Allah Tritunggal tidak ada perbedaan.

\section{Secara Ekonomis:}

Perbedaan secara ekonomi mengacu kepada aktifitas/karya Allah dalam sejarah penebusan. Apabila kita perhatikan dalam sejarah karya penebusan Allah terhadap manusia maka terlihat adanya perbedaan urutan atau prosedur dalam masing-masing pribadi Allah Tritunggal. Dalam karya-Nya Allah Bapa sebagaui yang pertama, Allah Putra sebagai yang kedua dan Allah Roh Kudus ketiga. Urutan ini bukan menunjukkan keunggulan diantara ketiganya tetapi mengacu kepada hikmat cara kerja dari Allah Tritunggal. Karena alasan ini maka Tuhan Yesus berkata "Kamu telah mendengar, bahwa Aku telah berkata kepadamu: Aku pergi, tetapi Aku datang kembali kepadamu. Sekiranya kamu mengasihi Aku, kamu tentu akan bersukacita karena Aku pergi kepada Bapa-Ku, sebab Bapa lebih besar dari pada Aku." Karena Ia (dalam rangka penebusan) membatasi diri-Nya seturut hikmat Allah Tritunggal (Rm. 11:33-35). Maka dapat dikatakan bahwa dalam rangka penebusan masing-masing pribadi dalam Allah Tritunggal memiliki tugas yang khusus yang dilaksanakan dalam kesatuan yang terpadu: Pemilihan (election) dan Penciptaan (Creation) adalah mengacu kepada Allah Bapa. (Ef. 1:4), Inkarnasi dan Penebusan mengacu pada Allah Anak, kelahiran baru dan Pengudusan adalah mengacu kepada Roh Kudus.

\section{Ketringgulan Allah dalam Alkitab}

Meskipun dalam Alkitab tidak ada pemakaian kata tritunggal ataupun istilah Tritunggal/Trinitas secara eksplisit, tetapi keberadaan Allah sebagai Allah Tritunggal secara implisit (tersirat) baik dalam PL maupun dalam PB.

\section{Dalam PL}

PL secara jelas menyatakan bahwa Allah itu Esa "Dengarlah, hai orang Israel: TUHAN itu Allah kita, TUHAN itu esa" (U1 6:4) sebagai suatu pernyataan yang kontras dengan

\footnotetext{
${ }^{8}$ Torrance, The Trinity 131.
} 
allah yang dipercaya oleh bangsa-bangsa di sekitar Israel yang bersifat Politheis. Ini memberitahukan kepada bangsa Israel bahwa Allah mereka bukanlah alam semeseta ini tetapi Allah adalah pencipta, penguasa dan pemelihara alam semesta ini (Yes 45:22; Maz 96:5). Bangsa Israel dala PL memahami bahwa ketika mereka menyebut nama Allah itu esa (echad) berarti Allah tiu sesungguhnya satu-satunya Allah yang di dalamnya terdapat kesatuan keAllah-an (God's unity) bukan dalam pengertian satu (yachid) yaitu satu secara numerikal/matematis yang absolut. Misalnya penggunaan dalam Kejadian 2:24 "Sebab itu seorang laki-laki akan meninggalkan ayahnya dan ibunya dan bersatu dengan isterinya, sehingga keduanya menjadi satu daging. Selain itu dalam beberapa kasus dalam PL menyatakan tentang satu dalam arti "kejamakan" Allah: Penggunaan kata "Elohim" yang merupakan bentuk jamak dari kata Eloah. Bahkan kata ini dipakai lebih dari 2500 kali dalam PL, Allah menyatakan atau membicarakan diri-Nya kepada manusia dalam bentuk jamak (Kej 1:26; 11:7). "Baiklah Kita menjadikan manusia menurut gambar dan rupa Kita, ... "Demikian juga dalam Yesaya 6:8 "Whom shall I send, and who will go for us?" (KJV). Kata ganti yang dipakai dalam ayat-ayat di atas adalah kata ganti dalam bentuk jamak, Theophani Allah. Malaikat Tuhan dalam PL memiliki dua pengertian, Pertama sebagai Malaikat (makhluk ciptaan) yang dibedakan dengan Allah. Malaikat berkata tentang Allah seperti dalam Kejadian 6:11; 22:12. Kedua, Malaikat sebagai pernyataan (Theophani) diri Allah, di mana Ia disamakan dengan Allah, Ia berkata sebagai Allah seperti dalam Kejadian 31:11-13; 16:10 22:17; 48:16; Hosea 12:3-5, Pernyataan PL mengenai pekerjaan Roh Kudus/Roh Allah, seperti dalam Kejadian 1:2; Hakim-hakim 6:34; Hagai 2:1-5.

\section{Dalam PB.}

Seperti halnya dalam PL, Perjanjian Baru juga menyatakan dengan jelas tentang Keesaan Allah. Seperti dalam 1 Korintus 8:4; Efesus 4:4,6; Yakobus 2:19
1 Timotius 1:17; 2:5 dan Yudas 25. Selain keesaan Allah, Perjanjian Baru khususnya tentang Allah Tritunggal lebih berkembang dan lebih nyata daripada dalam Perjanjian Lama. Gambaran tentang Ketritunggalan Allah dapat terlihat jelas melalui pernyataan tentang pribadi/oknum Allah.

\section{Allah Bapa.}

Dalam PB penyebutan Allah sebagai Allah Bapa lebih mempunyai arti khusus dan mengarah pada ketritunggalan Allah. Sebutan "Bapa" dibedakan dari Allah Anak dan Roh Kudus. "Bapa" seringkali dijelaskan sebagai: Allah' yang memelihara segala makhluk, yang besar dan kecil (Mat 6:26, 29; 10:29); Allah yang menyelidiki, memberi pahala dan hukuman (Mat 6:4, 18; 10:28; 13:43, Luk 12:45, Yoh 14:2; 17:24). Tetapi oknum "Bapa" berbeda dari oknum "Anak" sebab: Bapa yang mengutus Anak (Yoh. 5:30, 37, 43; 16:28; 20:21), Bapa telah menyerahkan segala sesuatu kepada Anak (Mat 11:27, Luk 10:22, Yoh 8:29); dan Bapa senantiasa beserta dengan Anak (Yoh. 6:57; 14:10). Juga dijelaskan bahwa oknum "Bapa" berbeda dari oknum Roh Kudus" sebab Bapa mengaruniakan Roh-Nya (Yoh 3:34).

\section{Allah Anak}

PB lebih jelas menyebutkan bahwa Yesus Kristus adalah Anak Allah. Gelar Yesus sebagai Anak berarti ketergantungan manusia Yesus dari Nazaret kepada Bapa Surgawi. Bapa adalah "Tuhan langit dan bumi" (Luk 10:21), kepada siapa Yesus berseru di taman Getsemani dengan panggilan yang akrab dan penuh arti "Abba" (Mrk 14:36), dan yang mengakui Yesus sebagai Anak-Nya pada saat pembaptisan dan pemuliaan (Mrk 1:11; 9:7). Pernyataan tentang Allah Anak adalah sebagai berikut: Anak dan Bapa adalah satu (Yohanes 14:10,11,18;17:21);sang Anak mengerjakan apa yang telah diperintahkan Bapa (Luk 2:49; 22:42, Yoh 8:28, 38; 10:32; 12:50; 15:10, 15); oleh karena itu, sang Anak dapat menuntut pahala dari sang Bapa (Yoh 14:16; 16:23, 26; 17:25). Berdasarkan ayat-ayat ini jelas bahwa Anak dibedakan dari Bapa, tetapi Anak adalah kepenuhan Allah yang telah dinyatakan (Yoh 1:14-18).

\section{Roh Kudus}

Perjanjian Baru menjelaskan bahwa Roh Kudus adalah kuasa dinamis Allah. Roh Kudus adalah "nafas" Allah, yaitu vitalitas dan hidupNya. Sama seperti bagi manusia, tubuh tanpa 
nafas adalah mati, demikian pula bagi Allah, nafas-Nya adalah vitalitas dan alat yang dengannya la bertindak dan menyatakan kekuasaan-Nya. Roh Kudus merupakan satu pribadi (Yoh 14:17, 26, Kis 10:19-23, Rm 8:14, 26-27; 15:30, 1Kor 12:11, Ef 1:17). Ia menjadi "Penolong" yaitu paralektos yang berarti "Penghibur" (Yoh. 14:16; 15:26). Roh Kudus juga dibedakan dari Bapa dan Anak. Roh Kudus bekerja di dalam Anak (Mat 12:28, Luk 4:18), Roh Kudus diutus oleh Bapa (Yoh 14:16, 26), dan juga oleh Anak (Yoh 15:26). Roh Kudus adalah pelaksana pekerjaan Kristus (Yoh 14:15-17, 25-26; $16: 4 b-15)$.

\section{Pernyataan Tentang Ketiga Oknum Allah}

Meskipun dalam Perjanjian Baru tidak ada doktrin Allah Tritunggal yang dinyatakan secara jelas, namun demikian, ada beberapa teks dianggap mengandung pernyataan mengenai hubungan ketiga oknum dalam Tritunggal. Beberapa teks tersebut adalah:

Matius 3:16-17, "Sesudah dibaptis, Yesus segera keluar darl air dan pada waktu Itu juga langlt terbuka dan la melihat

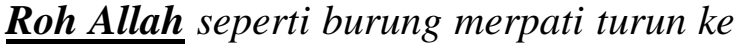
atas-Nya, lalu terdengarlah suara darl sorga yang mengatakan: "Inllah Anak-Ku yang Kukasihi, kepada-Nyalah Aku berkenan."

Matius 28:19,“Karena itu pergllah, jadikanlah semua bangsa murid-Ku dan baptislah mereka dalam nama Bapa dan Anak dan Roh Kudus."

2 Korintus 13:13 Kasih karunia Tuhan Yesus Kristus, dan kasih Allah, dan persekutuan Roh Kudus menyertai kamu sekalian

\section{KESIMPULAN}

Allah yang dapat kita kenal adalah sebatas apa yang dinyatakan dalam Alkitab. Allah yang menyatakan dalam Alkitab adalah Allah Tritunggal. Inilah yang harus dipahami oleh umat Kristiani. Ada hal-hal yang sepertinya kontradiksi tetapi sebenarnya bukan kontradiksi melainkan suatu misteri, yaitu misteri Allah yang tidak mungkin dipahami secara sempurna dengan kemampuan manusia yang terbatas. Bagian kita adalah memahami apa yang dinyatakan-Nya dalam Alkitab.

Doktrin Allah tritunggal bukanlah sebuah doktrin terlalu sulit, meskipun disisi lain kita juga tidak mungkin memahaminya secara sempurna. Melalui paper ini penulis berhar ap dapat membantu setiap umat Kristen dalam memahami doktrin Allah Tritunggal dan menerapkan secara praktis dalam kehidupan sehari-hari. Bapak Gereja Augustinus menyatakan tentang pentingnya membicarakan ajaran Allah Tritunggal dalam karyanya On Trinity sebagai berikut: "Kami harus berbi cara tentang Allah Tritunggal bukan oleh karena kami dapat memahaminya dengan sempurna, namun oleh karena kami tidak dapat menutup mulut kami untuk membicarakan hal yang pokok dari iman orang percaya."

\section{DAFTAR PUSTAKA}

Boff, Leonardo. Trinity and Society. New York: Orbis, 1988.

Burnaby, John. Augustine Later Works. Philadelphia: Westminster, t.t

End, Van Den. Harta dalam Bejana. Jakarta: Gunung Mulia, 1987.

Erickson, J Millard. Teologi Kristen Vol 1. Malang: Gandum Mas, 1999.

Fickett, Harold L. Jr. Kepercayaan Kaum Baptis, Suatu Pedoman. Semarang Sekolah Tinggi Teologia Baptis, 1992.

George, Tomoty \& Dockery, David. S. Ed. Baptist Theologians. Nashville, Tennessee: Broadman Press, 1990.

Macleod, Donald. Shared Life: The Trinity and the Fellowship of God's People. London: Scripture Union, 1987.

Newbigin, Lesslie. Injil dalam Masyarakat Majemuk. Jakarta: Gunung Mulia, 1999.

Niftrik, G. C. Van. dan Boland, B. J Dogmatika Masa Kini. Jakarta: Gunung Mulia, 1984.

Pengakuan Iman Baptis Tahun 1689. Semarang: Sekolah Tinggi Teologia Baptis Indonesia, 1992.

Roxburgh, Alan. "Rethingking Trinitarian Missiology" dalam Global Missiology for 21ST Century. Grand Rapids, Michigan: Baker Academic, 2000. 
Smith E. C. Perkembangan Gereja-gereja

Baptis. Semarang: Seminari Teologia

Baptis di Indonesia, tanpa tahun

Warfield, Benyamin. B. Biblical and

Theological Study. Philadelphia:

Presbyterian and Reformed, 1968. 